Vol. 5, No. 1, 2020

\title{
Penerapan Teknologi Budidaya Tanaman Jahe di Pekarangan Berbasis Pertanian Sehat di Desa Bokor, Kabupaten Malang
}

\author{
Husni Thamrin Sebayang ${ }^{1}$, Kartika Yurlisa², Eko Widaryanto² ${ }^{2}$ Nurul Aini ${ }^{2}$ \\ 1,2 Universitas Brawijaya, Indonesia
}

\begin{abstract}
A B S T R A C T
APPLICATION OF GINGER PLANT CULTIVATION TECHNOLOGY IN THE YARD BASED ON HEALTH AGRICULTURE IN BOKOR VILLAGE, MALANG DISTRICT. House yard is one of the lands that have the potential to be developed. The yard can be used by growing high-value commodity crops. To get high yields and productivity, Farmers must choose the right and proper cultivation techniques. Besides, to get the results in the form of healthy food products, the cultivation process must be carried out by reducing the input of chemical compounds into the farm business. Therefore, community service activities were carried out in Bokor Village, Tumpang Subdistrict, Malang Regency. It was aimed to utilize the house yard by planting ginger based on healthy agriculture. The target group is farmers in the Subur Farmers Group. The stages of activities which were carried out were counseling on the use of house yards, training in ginger cultivation, providing assistance in planting materials and media, and making demonstration plots. The results of community service show that farmers want to try to use the yard by planting ginger in their yard. It also increased knowledge of farmers about ginger cultivation following Good Agricultural Practice so that the use of the yard with proper agriculturebased ginger cultivation can be developed.

Keywords: Bokor Village, Ginger, Healthy Agriculture, Yard.

\begin{tabular}{llll}
\hline Received: & Revised: & Accepted: & Available online: \\
25.09 .2019 & 07.11 .2019 & 10.01 .2020 & 14.02 .2020 \\
\hline
\end{tabular}
\end{abstract}

\section{Suggested citation:}

Sebayang, H., Yurlisa, K., Widaryanto, E., Aini, N., \& Azizah, N. (2020). Penerapan teknologi budidaya tanaman jahe di pekarangan berbasis pertanian sehat di Desa Bokor, Kabupaten Malang. Jurnal Pengabdian Pada Masyarakat, 5(1), 45-50. https://doi.org/10.30653/002.202051.254

Open Access I URL: http://ppm.ejournal.id/index.php/pengabdian/article/view/254

${ }^{1}$ Corresponding Author: Jurusan Budidaya Pertanian Fakultas Pertanian Universitas Brawijaya; Jalan Veteran Malang 65145, Indonesia; Email; kartikayurlisa2@gmail.com 


\section{PENDAHULUAN}

Desa Bokor adalah satu dari 15 desa di Kecamatan Tumpang, terletak di bagian barat Kecamatan Tumpang, Kabupaten Malang. Desa Bokor mempunyai curah hujan $2600 \mathrm{~mm} /$ tahun, 6 bulan bulan basah, dan ketinggian $450 \mathrm{~m}$ dpl. Luas desa 130,95 ha. Potensi daerah terletak di bidang pertanian, 74,7\% luas lahan desa merupakan sawah dengan irigasi sepanjang tahun, sisanya merupakan tegalan, pekarangan dan juga fasilitas umum. Desa Bokor memiliki posisi yang penting yaitu berada di jalan utama Malang menuju Tumpang, dengan jarak tempuh ke Kota Malang sekitar 40-60 menit (tergantung dengan kondisi lalu lintas jalan). Jarak yang tidak jauh dari kota menjadi potensi untuk pengembangan pertanian dan Kota Malang dapat menjadi pangsa pasar produk pertanian.

Berdasarkan Peraturan Menteri Desa, Pembangunan Daerah Tertinggal, dan Transmigrasi Republik Indonesia Nomor 2 tahun 2016 tentang Indeks Desa Membangun (IDM), Desa Bokor mempunyai nilai IDM sebesar 0,587 dan dikategorikan sebagai desa tertinggal. Meskipun termasuk dalam desa tertinggal, masyarakat Desa Bokor memiliki motivasi untuk meningkatkan kesejahteraannya. Hal ini terlihat dari $78 \%$ keikutsertaan masyarakat ketika diundang pertemuan di desa.

Petani pada umumnya bertani dengan sistem budidaya konvensional yang menggunakan pestisida dan pupuk kimia yang berlebihan. Hal ini berdampak terjadinya pencemaran lingkungan dan peningkatan biaya usaha tani. Pertanian sehat yaitu sistem pertanian yang dapat menjaga keberlanjutan kesuburan dan produktivitas tanah, mengkonservasi tanah dan memperlambat laju degradasi tanah (Atmojo, 2007). Salah satu alternatif produksi bahan pangan yang sehat yaitu dengan cara mengaplikasikan sistem pertanian sehat. Sistem ini membudidayakan tanaman dengan masukan bahan kimia yang rendah, yang ke depannya akan menjamin keberlanjutan usaha tani.

Kondisi yang memprihatinkan yang terjadi pada saat ini yaitu menyempitnya lahan yang beririgasi karena kebutuhan sektor industri, pemukiman, proyek infrastruktur dan lain-lain (Soesastro et al, 2005). Untuk mengatasi alih fungsi lahan tersebut, dapat dilakukan diversifikasi usaha dengan memanfaatkan lahan pekarangan yang belum ditanami tanaman budidaya. Berdasarkan hasil observasi lapang, rumah penduduk di Desa Bokor umumnya memiliki pekarangan yang cukup luas dan belum dimanfaatkan untuk budidaya tanaman. Di lahan pekarangan dapat juga dilakukan usaha tani komersial, sehingga diharapkan dapat menjamin tersedianya makanan sehat dan bergizi di tingkat rumah tangga, dan juga meningkatkan pendapatan petani.

Pemilihan jenis tanaman yang dikembangkan di lahan pekarangan merupakan salah satu faktor yang menentukan keberhasilan teknik budidaya. Salah satu tanaman yang bisa dikembangkan di pekarangan yaitu tanaman jahe. Jahe merupakan tanaman rempah dan obat yang bernilai ekonomis tinggi (Widyastuti, 2015). Petani di Desa Bokor yang telah membudidayakan jahe jumlahnya masih sedikit. Tanaman jahe ditanam sebagai tanaman sela diantara sayuran, yang merupakan komoditas utama di daerah tersebut. Petani harus mengenali karakter jahe dan teknik budidaya jahe yang tepat, sehingga didapatkan hasil dan produktivitas tanaman yang maksimal. Berdasarkan hal tersebut, maka dilakukan kegiatan pengabdian kepada masyarakat dengan tema penerapan teknologi budidaya tanaman jahe di pekarangan berbasis pertanian sehat. 


\section{METODE}

Kegiatan pengabdian dilakukan di Desa Bokor, Kecamatan Tumpang, Kabupaten Malang dari bulan Juli sampai dengan September 2019. Masyarakat yang menjadi target dari kegiatan adalah kelompok tani Subur. Metode yang diaplikasikan yaitu mengadakan penyuluhan yang bertempat di Balai Desa Bokor. Kegiatan penyuluhan terdiri dari sambutan pihak desa dan ketua Laboratorium Sumber Daya Lingkungan Jurusan Budidaya Pertanian Fakultas Pertanian Universitas Brawijaya, penyampaian materi budidaya jahe, diskusi, pelatihan budidaya jahe di pekarangan, pembuatan demplot percontohan budidaya jahe di pekarangan, dan pemberian bantuan bahan dan media tanam. Jumlah peserta yang mengikuti kegiatan pengabdian masyarakat mencapai 20 peserta.

Peserta penyuluhan diberikan lembar kuisioner yang berisi pertanyaan post-test. Pertanyaan post-test dikerjakan setelah penyampaian materi untuk mengetahui tingkat ketertarikan peserta pada budidaya jahe di pekarangan. Angket post-test mencangkup 4 pertanyaan, yaitu: 1) Tanggapan petani tentang kebermanfaatan kegiatan penyuluhan; 2) Kesediaan petani untuk menggunakan lahan pekarangan yang dimiliki untuk bercocok tanam jahe; 3) Pendapat petani mengenai tingkat kesulitan dalam teknologi budidaya pekarangan; 4) Tanggapan peserta tentang kebermanfaatan bercocok tanam jahe di pekarangan.

Pada akhir kegiatan dilakukan evaluasi untuk mengukur keberhasilan pelaksanaan kegiatan, baik dari segi teori, maupun kebermanfaatan yang diperoleh oleh petani.

\section{HASIL DAN PEMBAHASAN}

Jahe adalah salah satu jenis tanaman rempah yang sedang banyak dikembangkan oleh petani. Jahe dapat diolah menjadi pemberi aroma, bumbu masakan dan rasa pada makanan juga minuman, berbagai minuman dan banyak bentuk olahan lainnya. Selain sebagai bahan minuman dan makanan, jahe mempunyai banyak khasiat diantaranya adalah untuk menurunkan asam urat, menurunkan kolestrol dan banyak khasiat yang bisa diperoleh dari tanaman tersebut (Hapsari \& Rahayuningsih, 2014; Lallo, 2018). Karena itu dapat disimpulkan jahe mempunyai nilai ekonomis yang tinggi.

Budidaya jahe di pekarangan memiliki peluang usaha yang cukup baik. Akan tetapi, banyak petani yang belum mengenal dan mengetahui teknik budidaya jahe di pekarangan yang tepat. Oleh karena itu pengetahuan mengenai teknik budidaya jahe di pekarangan perlu disebarluaskan kepada penduduk di Desa Bokor, Kecamatan Tumpang, Kabupaten Malang (Gambar 1). 


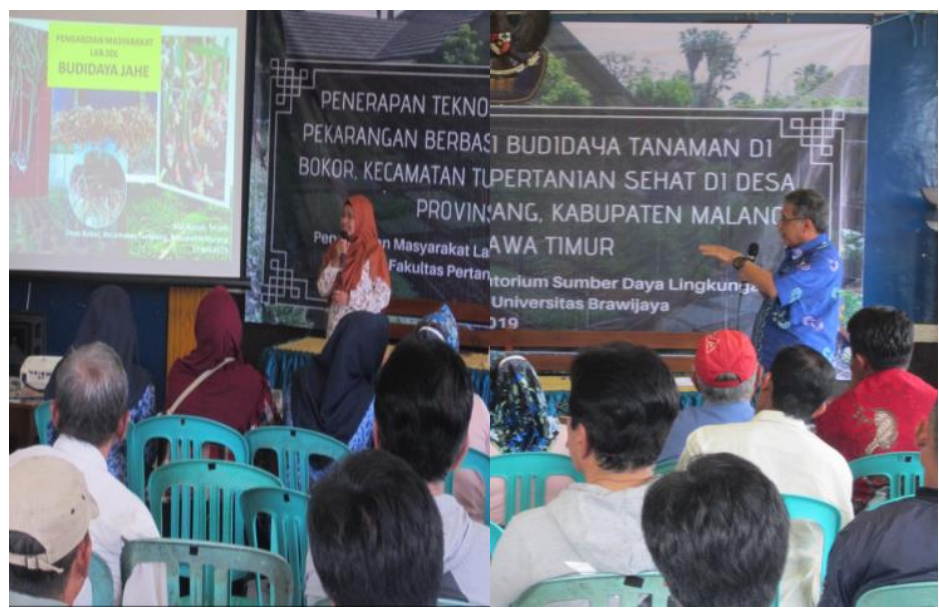

Gambar 1. Penyuluhan Budidaya Jahe di Balai Desa Bokor, Tumpang, Kab. Malang

Kegiatan penyampaian materi dilakukan untuk meningkatkan pengetahuan petani mengenai SOP budidaya tanaman jahe di pekarangan sehingga akan memproduksi hasil yang maksimal. Peningkatan pengetahuan dilaksanakan dengan menyampaikan materi di depan peserta penyuluhan. Dengan harapan peserta penyuluhan dapat memberikan informasi yang didapat ke seluruh warga lain di desanya, sehingga informasi dapat tersebar juga kepada penduduk yang tidak mendapatkan penyuluhan.

Selain kegiatan penyuluhan, juga dilaksanakan pelatihan dan demplot budidaya jahe di pekarangan. Selain itu juga dilakukan pemberian bantuan bahan dan media tanam kepada petani. Dokumentasi kegiatan pelatihan budidaya jahe di pekarangan, demplot dan pemberian bantuan bahan dan media tanam disajikan pada Gambar 2 .

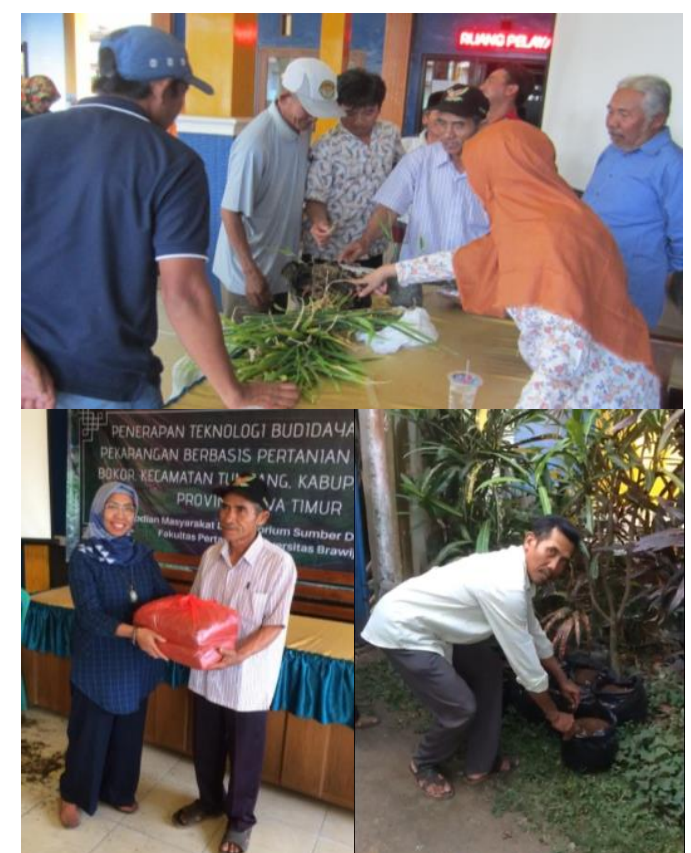

Gambar 2. Pelatihan, Pemberian Bantuan Bahan dan Media Tanam, dan Pembuatan Demplot Budidaya Jahe di Pekarangan 
Pada akhir acara penyuluhan dilaksanakan evaluasi berupa angket pertanyaan yang bertujuan untuk mengetahui respon dan antusias peserta terhadap kegiatan pengabdian masyarakat. Berdasarkan hasil post-test (Tabel 1), sebanyak 100\% peserta berpendapat kegiatan penyuluhan budidaya tanaman di pekarangan berbasis pertanian sehat bermanfaat bagi mereka. Semua peserta (100\%) mempunyai keinginan untuk mencoba sendiri budidaya tanaman di pekarangan rumahnya masing-masing. Mayoritas peserta (67\%) berpendapat bahwa teknik budidaya tanaman di pekarangan termasuk mudah untuk dilakukan. Mayoritas keuntungan yang didapat dalam budidaya tanaman di pekarangan yaitu mendapat kebutuhan pangan sehat keluarga (37\%) dan lingkungan pekarangan menjadi lebih asri dan nyaman (34\%). Di lain sisi, warga yang berpendapat bahwa budidaya pekarangan bisa meningkatkan pendapatan masih berjumlah sedikit (29\%).

Tabel 1. Hasil Post-Test Peserta Program

\begin{tabular}{|c|c|c|c|}
\hline No. & Pertanyaan & Jawaban & Jumlah (\%) \\
\hline 1. & $\begin{array}{l}\text { Apa yang Bapak/Ibu rasakan } \\
\text { setelah mendapatkan } \\
\text { penyuluhan budidaya tanaman } \\
\text { di pekarangan berbasis } \\
\text { pertanian sehat? }\end{array}$ & $\begin{array}{l}\text { a. Bermanfaat, } \\
\text { b. Biasa saja, } \\
\text { c. Tidak ada manfaatnya. }\end{array}$ & $\begin{array}{c}100 \\
0 \\
0\end{array}$ \\
\hline 2. & $\begin{array}{l}\text { Setelah mengikuti penyuluhan } \\
\text { ini, apakah Bapak/Ibu berniat } \\
\text { mencoba sendiri budidaya } \\
\text { tanaman di pekarangan di } \\
\text { rumah? }\end{array}$ & $\begin{array}{l}\text { a. Ya pasti } \\
\text { b. Ragu-ragu/belum tahu } \\
\text { c. Tidak }\end{array}$ & $\begin{array}{c}100 \\
0 \\
0\end{array}$ \\
\hline 3. & $\begin{array}{l}\text { Bagaimana menurut Bapak/Ibu } \\
\text { tentang teknologi budidaya } \\
\text { tanaman di pekarangan } \\
\text { sendiri? }\end{array}$ & $\begin{array}{l}\text { a. Mudah, } \\
\text { b. Susah, } \\
\text { c. Sedang. }\end{array}$ & $\begin{array}{c}67 \\
6 \\
28\end{array}$ \\
\hline 4. & $\begin{array}{l}\text { Menurut Bapak/Ibu, apa } \\
\text { keuntungan menerapkan } \\
\text { budidaya tanaman di } \\
\text { pekarangan? }\end{array}$ & $\begin{array}{l}\text { a. Mendapatkan kebutuhan } \\
\text { pangan sehat keluarga, } \\
\text { b. Lingkungan pekarangan } \\
\text { menjadi lebih asri dan } \\
\text { nyaman, } \\
\text { c. Produk hasil budidaya } \\
\text { pekarangan dapat } \\
\text { diperjualbelikan, untuk } \\
\text { menambah pendapatan } \\
\text { keluarga, } \\
\text { d. Tidak ada untungnya. }\end{array}$ & $\begin{array}{l}37 \\
34\end{array}$ \\
\hline
\end{tabular}

Program penyuluhan budidaya jahe di pekarangan telah berhasil menginformasikan teknologi budidaya yang tepat untuk pengembangan tanaman rempah dan sekaligus memotivasi para petani untuk menanam pekarangan rumahnya dengan tanaman yang bermanfaat. Antusias warga sangat tinggi untuk mengembangkan desanya. Apabila dilihat dari letak desa yang merupakan jalan 
menuju ke gunung bromo, Desa Bokor mempunyai potensi untuk pengembangan bidang pariwisata ke arah agrowisata pertanian sehat. Dalam rangka pengembangan menuju desa wisata maka diperlukan pengembangan sumber daya manusia yang trampil dan memahamu pentingnya lingkungan pertanian yang sehat.

\section{SIMPULAN}

Budidaya jahe di pekarangan Desa Bokor Kecamatan Tumpang Kabupaten Malang telah mampu memberikan dampak positif yang signifikan kepada petani, yaitu melalui penyuluhan dan pelatihan budidaya sesuai dengan Good Agricultural Practices. Keberlanjutan program penyuluhan mengenai pertanian sehat mampu mendukung kesehatan masyarakat, melalui penyediaan pangan sehat. Pembinaan dan pendampingan masih perlu dilakukan untuk meningkatkan kesejahteraan masyarakat daerah tersebut.

\section{REFERENSI}

Atmojo, S. W. (2007). Pertanian Organik, Integrasi Ternak dan Tanaman. Solo Pos, 7 Maret 2007.

Hapsari, H. P., \& Rahyuningsih, H. M. (2014). Pengaruh pemberian jahe merah (Zingiber officinale var rubrum) terhadap Kadar Kolestrol LDL Wanita Dislipidemia. Journal of Nutrition College, 3 (4), 871-879.

Lallo, S., Mirwan, M., Palino, A., Nursamsiar., \& Hardianti, B. (2018). Aktifitas ekstrak jahe merah dalam menurunkan asam urat pada kelinci serta isolasi dan indentifikasi senyawa bioaktifnya. Jurnal Fitofarmaka Indonesia, 5 (1), 271-278.

Menteri Desa, Pembangunan Daerah Tertinggal, dan Transmigrasi Republik Indonesia. (2016). Peraturan Nomor 2 tahun 2016 pasal 4 tentang Indeks Desa Membangun. Jakarta.

Soesastro, H., Budiman, A., Triaswati, N., Alisjahbana, A., \& Adiningsih, S. (2005). Permasalahan Ekonomi di Indonesia dalam Setengah Abad Terakhir. Yogyakarta: Kanisius.

Widyastuti, E. (2015). Analisis ekonomi dan strategi pengembangan komoditas jahe gajah di Desa Pace Kecamatan Silo Kabupaten Jember. (Skripsi) Jember: Universitas Jember, Indonesia.

\section{Copyright and License}

This is an open access article distributed under the terms of the Creative Commons Attribution 4.0 International License, which permits unrestricted use, distribution, and reproduction in any medium, provided the original work is properly cited.

(C) 2020 Husni Thamrin Sebayang, Kartika Yurlisa, Eko Widaryanto, Nurul Aini. 